\title{
Synthesis of Azoles Condensed with, or Linked to, Nitroxides
}

\author{
Balázs Bognára \\ Tamás Kálaia,b \\ Gergely Fekete Gulyás ${ }^{c}$ \\ Noémi Lazsányi ${ }^{a}$ \\ Kálmán Hideg*a \\ ${ }^{a}$ Institute of Organic and Medicinal Chemistry, University of \\ Pécs, Szigeti st. 12, 7624 Pécs, Hungary \\ b Szentágotai Research Centre, Ifjúság st. 20, 7624 Pécs, \\ Hungary \\ ' Department of Pharmacognosy, University of Pécs, Rókus st. \\ 2, 7624 Pécs, Hungary \\ kalman.hideg@aok.pte.hu \\ Dedicated to Prof. Sándor Antus on the occasion of his $70^{\text {th }}$ \\ birthday
}
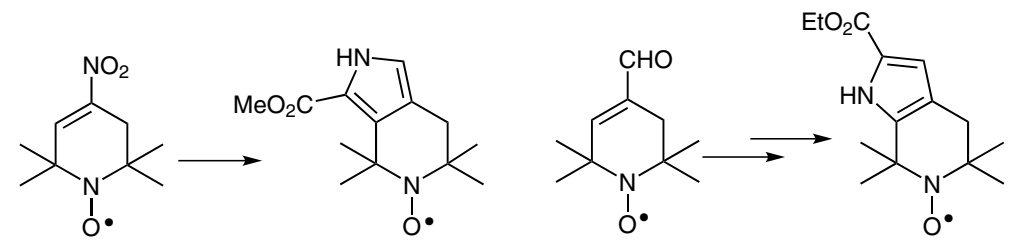

Received: 29.07.2014

Accepted after revision: 06.12.2014

Published online:

DOI: 10.1055/s-0034-1379958; Art ID: ss-2014-n0473-op

Abstract Nitroxides connected to indoles, tetrazoles, or 1,3,4-oxadiazoles were synthesized by conventional and microwave-assisted cyclization reactions. New approaches to pyrrole-, pyrazole-, and triazoleannulated nitroxides are described. We showed that Diels-Alder reactions of the $\mathrm{N}$-tert-butoxycarbonyl derivative of (4,4,6,6-tetramethyl2,4,6,7-tetrahydro-5H-pyrrolo[3,4-c]pyridin-5-yl)oxidanyl gave polycyclic scaffolds condensed with a six-membered nitroxide.

Key words azides, cyclizations, nitriles, pyrroles, free radicals

The importance of heterocyclic chemistry in the life sciences was discovered at the nascent stage of organic chemistry, two centuries ago, with the isolation of alkaloids such as quinine, morphine, and camptothecin. It later emerged that endogenous neurotransmitters (histamine and serotonin) contain heterocyclic units (imidazole and indole), and today it is evident that heterocycles play an important role in drug research and medicinal chemistry. Heterocyclecontaining drugs are used in all therapeutic areas, including cardiovascular and metabolic diseases and diseases of the central nervous system. Heterocycles are also present in antiinflammatory, antiulcer, and antiinfective drugs, among others. ${ }^{1}$

Nitroxides are stable free-radical species that have a wide range of applications across many scientific disciplines, including materials science, biophysics, molecular biology, and medicine. ${ }^{2}$ Nitroxides are often used as initiators for the preparation of functional and complex polymers, oxidants in organic chemistry, ${ }^{3}$ spin labels in identifying structures of biomolecules, ${ }^{4}$ building blocks for organic magnets, ${ }^{5}$ and dynamic nuclear polarization agents in NMR spectroscopy, ${ }^{6}$ among many other applications.
In recognition of the importance of these areas, we have a long-standing interest in modifying heterocycles with stable nitroxide free radicals, principally through $\mathrm{C}-\mathrm{C}$ bond formation or by condensation procedures, bearing in mind that heteroatoms should remain unaffected. In compliance with this requirement, we have synthesized a number of nitroxides condensed with pyrrole, furan, pyridine, ${ }^{7}$ quinoline ${ }^{8}$ thiophene, ${ }^{9}$ isothiazole,${ }^{10}$ or selenophene ${ }^{11}$ moieties, thereby providing access to paramagnetic analogues of omeprazole $^{7}$ and tacrine ${ }^{12}$ and to their diamagnetic precursors.

In continuation of this research interest, we examined the synthesis of several new paramagnetic tetrazole, oxadiazole, indole, pyrazole, triazole, and pyrrole derivatives modified with both five- and six-membered nitroxides in the hope that they would serve as useful paramagnetic building blocks for constructing spin labels, bioactive compounds, or even supramolecular scaffolds.

Tetrazoles coupled to five- and six-membered nitroxide were obtained by treatment of the paramagnetic nitriles 1a-c $\mathbf{c}^{13-15}$ with two equivalents of sodium azide and ammonium chloride in $\mathrm{N}, \mathrm{N}$-dimethylformamide ${ }^{16}$ at $130{ }^{\circ} \mathrm{C}$ in a microwave oven to give the corresponding tetrazoles $\mathbf{2 a - c}$ in $37-64 \%$ isolated yield (Scheme 1). As the nitroxide function was not destroyed, even on longer (two hours) microwave irradiation, we decided to study this reaction with more complex paramagnetic nitriles.

By applying this approach, we attempted a synthesis of a 3,4-bis(tetrazolyl)pyrroline nitroxide. First, we synthesized dinitrile 4 by treatment of bromo nitrile $3^{9}$ with tetraethylammonium cyanide in acetonitrile (Scheme 2). However, the reaction of dinitrile $\mathbf{4}$ with six equivalents of sodium azide and ammonium chloride for a prolonged reaction time (three hours) gave the monotetrazolyl derivative $\mathbf{5}$ instead of the desired bistetrazolyl derivative. Treatment of 

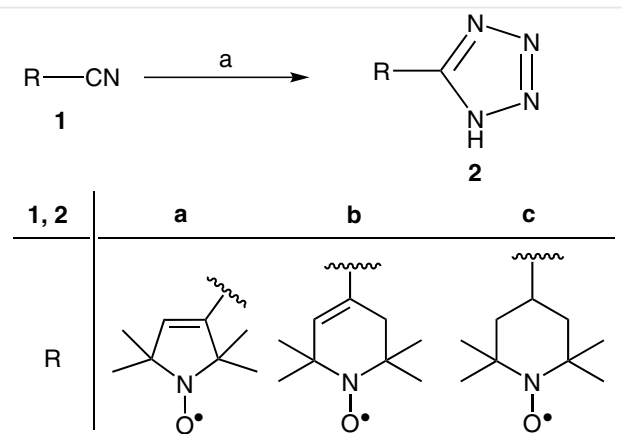

Scheme 1 Reagents and conditions: (a) $\mathrm{NaN}_{3}$ (2.0 equiv), $\mathrm{NH}_{4} \mathrm{Cl}$ (2.0 equiv), DMF, $2 \mathrm{~h}, 130^{\circ} \mathrm{C}(\mathrm{MW}), 51-58 \%$.

bromo nitrile 3 under these reaction conditions, somewhat unexpectedly, gave the tetrahydropyrrolo[3,4-b]pyrrole derivative 7, offering a new approach for the synthesis of condensed pyrazole rings, albeit in low yield (27\%). To obtain some information on the mechanism of the reaction, we examined the reaction of bromo nitrile $\mathbf{3}$ with sodium azide in $\mathrm{N}, \mathrm{N}$-dimethylformamide at $50^{\circ} \mathrm{C}$. After heating the mixture for 15 minutes, we were able to isolate an unstable yellow compound 6 that showed a nitrile band $\left(2217 \mathrm{~cm}^{-1}\right)$ and an azide band $\left(2108 \mathrm{~cm}^{-1}\right)$ in its IR spectrum (see Supporting Information), suggesting the formation of a $\beta$-azido $\alpha, \beta$-unsaturated nitrile intermediate that undergoes ring closure to form the pyrazole derivative $\mathbf{7}$.

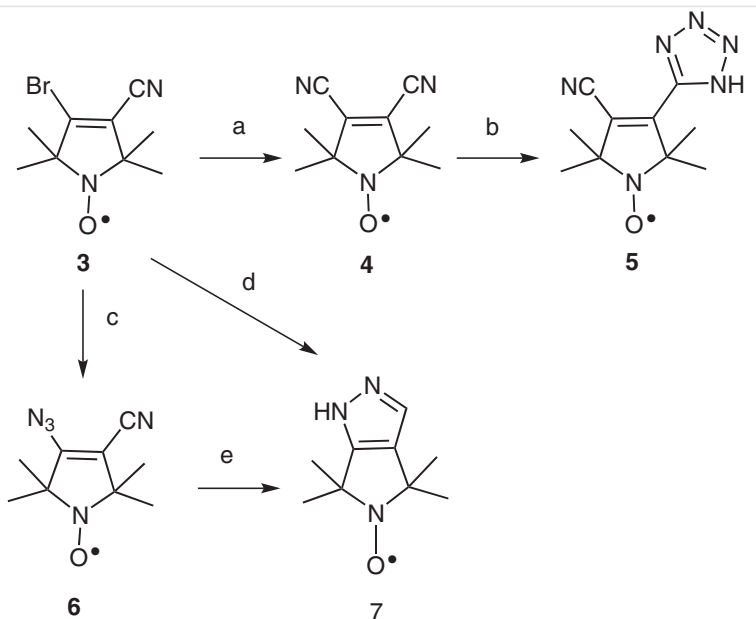

Scheme 2 Reagents and conditions: (a) $\mathrm{Et}_{4} \mathrm{NCN}$ (1.2 equiv), MeCN, reflux, 2 h, 74\%; (b) $\mathrm{NaN}_{3}$ (6.0 equiv), $\mathrm{NH}_{4} \mathrm{Cl}$ (6.0 equiv), DMF, $3 \mathrm{~h}, 130^{\circ} \mathrm{C}$ (MW), 43\%; (c) $\mathrm{NaN}_{3}$ (2.0 equiv), DMF, $50{ }^{\circ} \mathrm{C}, 15 \mathrm{~min}$., 35\%; (d) $\mathrm{NaN}_{3}$ (2.0 equiv), $\mathrm{NH}_{4} \mathrm{Cl}$ (2.0 equiv), DMF, $2 \mathrm{~h}, 130^{\circ} \mathrm{C}(\mathrm{MW}), 27 \%$; (e) DMF, 2 h, $130{ }^{\circ} \mathrm{C}(\mathrm{MW}), 30 \%$.

The spin-labeled tetrazole 2a proved to be a useful substrate for transformation into a substituted 1,3,4-oxadiazole by means of the Huisgen tetrazole rearrangement. ${ }^{17,18} \mathrm{By}$ heating tetrazole $\mathbf{2 a}$ in acetic anhydride at $90{ }^{\circ} \mathrm{C}$ in a microwave oven, we obtained oxadiazole 8 in $63 \%$ yield, whereas conventional heating of tetrazole $\mathbf{2 a}$ in acetic anhydride gave oxadiazole $\mathbf{8}$ in $45 \%$ yield. Acylation of tetrazole $\mathbf{2 a}$ with acyl chloride $\mathbf{9}^{13}$ in refluxing toluene containing pyridine gave the biradical compound 10, providing a new approach for the synthesis of biradicals ${ }^{19}$ (Scheme 3 ).
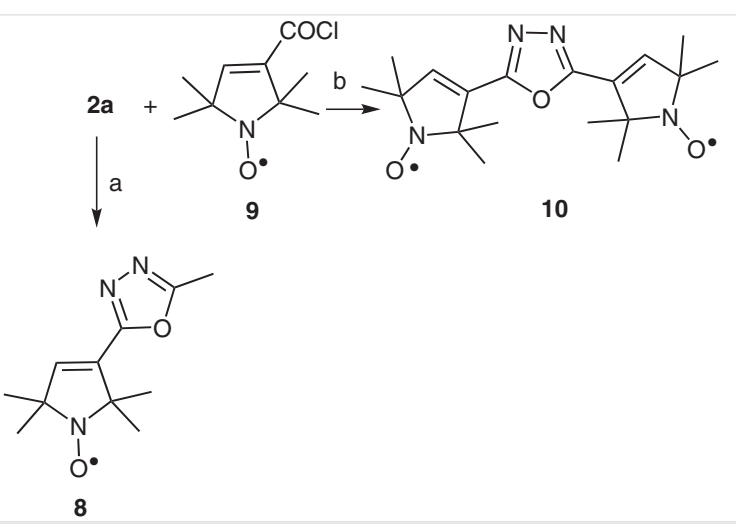

Scheme 3 Reagents and conditions: (a) Method $\mathrm{A}: \mathrm{Ac}_{2} \mathrm{O}$ (excess), $1 \mathrm{~h}$, $90{ }^{\circ} \mathrm{C}(\mathrm{MW}), 63 \%$; Method $\mathrm{B}$ : $\mathrm{Ac}_{2} \mathrm{O}$ (excess), $1 \mathrm{~h}, 90^{\circ} \mathrm{C}, 45 \%$; (b) 9 (1.0 equiv), py (1.0 equiv), toluene, $90^{\circ} \mathrm{C}, 1 \mathrm{~h}, 54 \%$.

We have previously reported ${ }^{7}$ a synthesis of 1,1,3,3-tetramethyl-1,2,3,5-tetrahydropyrrolo[3,4-c]pyrrole scaffold lacking any substituent on the pyrrole ring. A possible route to 2-(ethoxycarbonyl)pyrroles and -indoles is provided by the Hemetsberger-Knittel reaction; ${ }^{20,21}$ this inspired us to attempt syntheses of pyrrole-annulated five- or six-membered nitroxides.

Condensation of the $\alpha, \beta$-unsaturated nitroxide aldehydes 11a and $\mathbf{1 1} \mathbf{b}^{22,23}$ with ethyl 2-azidoacetate in anhydrous ethanol at $-10{ }^{\circ} \mathrm{C}$ in the presence of sodium ethoxide as a base gave the corresponding vinyl azides $\mathbf{1 2 a}$ and $\mathbf{1 2 b}$ in moderate yields (19-35\%). ${ }^{24}$ The vinyl azides were isolated and heated in anhydrous hexane with microwave irradiation to give the cyclized products $\mathbf{1 3} \mathbf{a}$ and $\mathbf{1 3 b}$ in $70-82 \%$ yield. To extend this work to substituted indoles, the paramagnetically modified benzaldehyde $\mathbf{1 4}^{25}$ was treated with ethyl 2-azidoacetate under the above conditions to give nitroxide 15a in satisfactory (60\%) yield. However, an attempt to cyclize nitroxide 15a to form the spin-labeled indole-2carboxylate 16a failed. We assume that the indole ring-formation reaction involves a free-radical step or a nonionic reactive intermediate-producing step. This idea was supported by the fact that the corresponding diamagnetic derivative $\mathbf{1 5 b}$, obtained by acetylation of the $N$-hydroxy derivative of 15a, ${ }^{26}$ underwent cyclization smoothly on microwave heating to give the acetate $\mathbf{1 6 b}$. Subsequent removal of the acetyl group by Zemplen's method ${ }^{27}$ gave our target compound 16a (Scheme 4). 
<smiles>CCOC(=O)/C=C1/C=C(CC)C(C)(CC)N([O])C(C)(CC)C1</smiles>

11

12

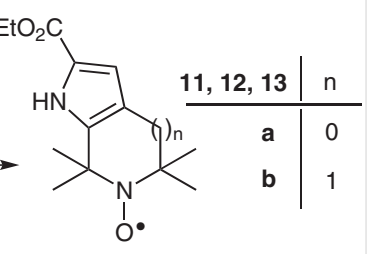

13

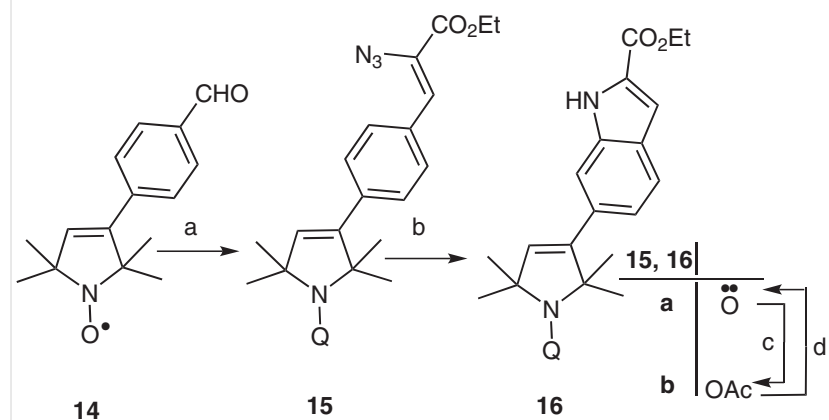

Scheme 4 Reagents and conditions: (a) NaOEt (2.0 equiv), $\mathrm{N}_{3} \mathrm{CH}_{2} \mathrm{CO}_{2} \mathrm{Et}$ (2.0 equiv), anhyd EtOH, $-10^{\circ} \mathrm{C}, 3 \mathrm{~h}, 19-60 \%$; (b) 12a, 12b, or 15b, anhyd hexane, $150^{\circ} \mathrm{C}(\mathrm{MW}), 15 \mathrm{~min}, 65-82 \%$; (c) 15 a (1.0 equiv), sodium ascorbate (5.0 equiv), aq 1,4-dioxane $\left(40^{\circ} \mathrm{C}\right), \mathrm{N}_{2}$, then $\mathrm{Et}_{3} \mathrm{~N}$ (1.1 equiv), $\mathrm{AcCl}$ (1.1 equiv), $0^{\circ} \mathrm{C}$ to r.t., $73 \%$; (d) $\mathrm{NaOEt}$ (3.0 equiv), $\mathrm{EtOH}, 30 \mathrm{~min}$. r.t., $71 \%$.

We also examined the original Hemetsberger-Knittel reaction, and we found that ring closure occurred in the presence of 0.1 equivalents of 2,2,6,6-tetramethylpiperidine-1-yloxyl (TEMPO ); however, many byproducts (decarboxylated products, dihydroindoles, dimers, etc.; see Supporting Information) were formed under the thermolysis conditions (Scheme 5).<smiles>CCOC(=O)c1cc2cc(-c3ccc([N+](=O)[O-])cc3)ccc2[nH]1</smiles><smiles>CCOCCOC(=O)C1Cc2ccccc2N1</smiles>

Scheme 5 Products of the Hemetsberger-Knittel reaction in the presence of TEMPO, based on a GC/MS study.

To synthesize the pyrrolo[3,4-c]pyridine isomer of the 13b scaffold, we used the Barton-Zard reaction. ${ }^{28}$ Elimination of hydrogen bromide from the bromo nitro derivative $\mathbf{1 7}^{29}$ by treatment with 1,8-diazabicyclo[5.4.0]undec-7-ene (DBU) in acetonitrile gave nitro compound 18. On heating with sodium azide in dimethyl sulfoxide, nitro compound 18 gave the condensed triazole derivative $19,{ }^{30}$ whereas treatment of $\mathbf{1 8}$ with methyl isocyanoacetate in tetrahydrofuran in the presence of DBU gave the condensed pyrrole derivative 20a. ${ }^{31}$ We surmised that not only is compound 20a a paramagnetic heterocyclic unit, but also that it can also be regarded as a precursor of a diene. Diene-like activity of the pyrrole ring was demonstrated by preparing the corresponding $N$-tert-butoxycarbonyl derivative $\mathbf{2 0 b}$, by treating 20a with di-tert-butyl dicarbonate in the presence of potassium tert-butoxide in tetrahydrofuran. ${ }^{32}$ Heating a mixture of compound 20b with diethyl acetylenedicarboxylate in refluxing toluene gave adduct 21, providing a new possibility for the synthesis of polycyclic ring systems ${ }^{33}$ containing a nitroxide unit (Scheme 6).

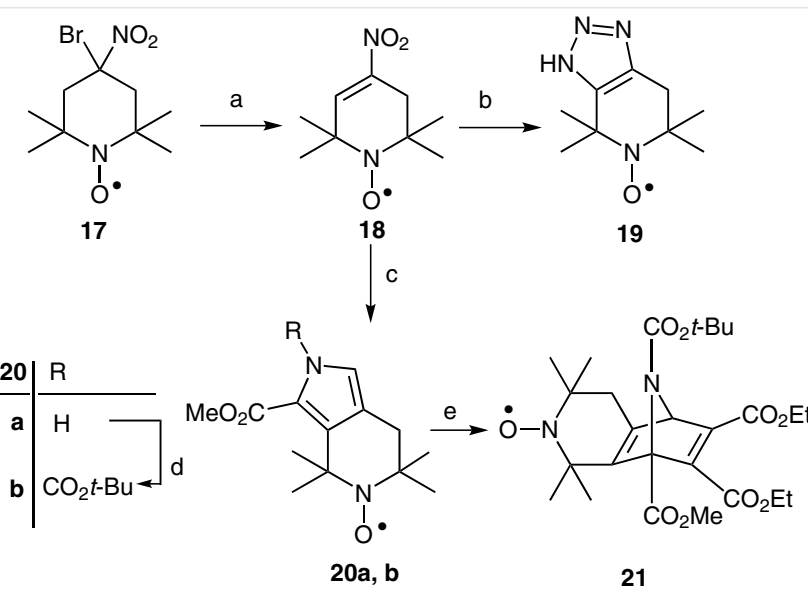

Scheme 6 Reagents and conditions: (a) DBU (1.1 equiv), MeCN, reflux, $15 \mathrm{~min}, 48 \%$; (b) $\mathrm{NaN}_{3}$ (2.0 equiv), DMSO, $90^{\circ} \mathrm{C}, 2 \mathrm{~h}, 47 \%$; (c) $\mathrm{NCCH}_{2}-$ $\mathrm{CO}_{2} \mathrm{Me}$ (1.1 equiv), DBU (1.2 equiv), THF, $0{ }^{\circ} \mathrm{C}$ to r.t., $12 \mathrm{~h}, 53 \%$; (d)(Boc) ${ }_{2} \mathrm{O}$ (1.1 equiv), $t$-BuOK ( 0.4 equiv), THF, reflux, $19 \mathrm{~h}, 73 \%$; (e) $\mathrm{EtO}_{2} \mathrm{CC} \equiv \mathrm{CCO}_{2} \mathrm{Et}$ (2.0 equiv), toluene, reflux, $48 \mathrm{~h}, 34 \%$.

In conclusion, we have developed a synthesis of pyrroline or tetrahydropyridine nitroxide-condensed pyrrole, pyrazole, or triazole heterocycles. By means of conventional or microwave-assisted heating, we synthesized nitroxides linked to tetrazole, indole, or oxadiazole moieties. We concluded that the classical Hemetsberger-Knittel indole synthesis is perturbed by the presence of stable nitroxide free radicals, whereas nitroxide-indole conjugates can be prepared directly through reversible protection of the nitroxide moiety. Further studies on pyrrole-condensed nitroxides are in progress in our laboratory.

Melting points were determined with a Boetius micro-melting point apparatus and are uncorrected. Elemental analyses (C, H, N, and S) were performed with a Fisons EA 1110 CHNS elemental analyzer. Mass spectra were recorded on a ThermoQuest Automass Multi spectrometer. NMR spectra were recorded on a Bruker Avance III Ascend 500 spectrometer; chemical shifts are referenced to TMS. The paramagnetic compound was reduced with five equivalents of hydrazobenzene/radical. Measurements were performed at a probe temperature of $298 \mathrm{~K}_{\text {in }} \mathrm{CDCl}_{3}$ solution. ESR spectra were recorded on Miniscope MS 200 in $10^{-4} \mathrm{M} \mathrm{CHCl}_{3}$ solution. All monoradicals gave a triplet line at $\mathrm{a}_{\mathrm{N}}=14.4 \mathrm{G}$; biradical $10\left(\mathrm{a}_{\mathrm{N}} 1=7.2 \mathrm{G} ; \mathrm{a}_{\mathrm{N}} 2=14.4 \mathrm{G}\right)$ gave a quintet line. Microwave-assisted reactions were carried out in a Milestone 
MicroSYNTH Labstation in sealed tubes (15 bar) with temperature control (fiber optic probe). The total irradiation time was as indicated. IR spectra were recorded a with Bruker Alpha FT-IR instrument with ATR support (ZnSe plate). Flash column chromatography was performed on Merck Kieselgel 60 (0.040-0.063 mm). Qualitative TLC was carried out on commercially available plates $(20 \times 20 \times 0.02 \mathrm{~cm})$ coated with Merck Kieselgel GF254. Compounds $1 \mathbf{1 a},{ }^{13} \mathbf{1 b},{ }^{14} \mathbf{1 c},{ }^{15} \mathbf{3},{ }^{9} \mathbf{9},{ }^{13}$ $\mathbf{1 1 a},{ }^{22} \mathbf{1 1 b},{ }^{23} \mathbf{1 4},{ }^{25}$ and $\mathbf{1 7}^{29}$ were prepared according to published procedures; other reagents were purchased from Aldrich or Alfa Aesar.

\section{Paramagnetic Tetrazoles 2a-c; General Procedure}

A mixture of $\mathrm{NaN}_{3}$ (130 mg, $\left.2.0 \mathrm{mmol}\right), \mathrm{NH}_{4} \mathrm{Cl}(107 \mathrm{mg}, 2.0 \mathrm{mmol}$ ), and the appropriate paramagnetic nitrile 1a-c $(1.0 \mathrm{mmol})$ in $\mathrm{DMF}(10$ $\mathrm{mL}$ ) was heated in a sealed tube by microwave irradiation for $2 \mathrm{~h}$ (hold time) at $130^{\circ} \mathrm{C}$. The mixture was then cooled and concentrated in vacuo. The residue was partitioned between $5 \% \mathrm{aq} \mathrm{H}_{2} \mathrm{SO}_{4}(10 \mathrm{~mL})$ and $\mathrm{CHCl}_{3}(15 \mathrm{~mL})$. The organic phase was separated and the aqueous phase was washed with $\mathrm{CHCl}_{3}(20 \mathrm{~mL})$. The organic phases were then combined, dried $\left(\mathrm{MgSO}_{4}\right)$, filtered, concentrated, and purified by flash column chromatography [silica gel, $\mathrm{CHCl}_{3}-\mathrm{MeOH}(4: 1)$ ].

\section{[2,2,5,5-Tetramethyl-3-(1H-tetrazol-5-yl)-2,5-dihydro-1H-pyrrol-} 1-yl]oxidanyl (2a)

Yellow crystals; yield: $120 \mathrm{mg}(58 \%) ; \mathrm{mp} 211-212^{\circ} \mathrm{C} ; R_{f}=0.27$ $\left(\mathrm{CHCl}_{3}-\mathrm{MeOH}, 4: 1\right)$.

IR (ATR): 2981, 2863, 2732, $1684 \mathrm{~cm}^{-1}$.

${ }^{1} \mathrm{H}$ NMR [?? $\left.\mathrm{MHz}, \mathrm{CDCl}_{3}+(\mathrm{PhNH})_{2}-\mathrm{CDCl}_{3}\right]: \delta=6.51(\mathrm{~s}, 1 \mathrm{H}), 1.68(\mathrm{~s}, 6$ $\mathrm{H}), 1.48(\mathrm{~s}, 6 \mathrm{H})$.

MS (EI): $m / z(\%)=208$ (69) [M+], 178 (26), 165 (69), 135 (100).

Anal. Calcd for $\mathrm{C}_{9} \mathrm{H}_{14} \mathrm{~N}_{5} \mathrm{O}: \mathrm{C}, 51.91 ; \mathrm{H}, 6.78 ; \mathrm{N}, 33.63$. Found: C, 52.01; H, 6.82; N, 33.58.

\section{[2,2,6,6-Tetramethyl-4-(1H-tetrazol-5-yl)-1,2,5,6-tetrahydropyri-} din-1(2H)-yl]oxidanyl (2b)

?? ; yield: $113 \mathrm{mg}(51 \%) ; \mathrm{mp} 169-170{ }^{\circ} \mathrm{C} ; R_{f}=0.38\left(\mathrm{CHCl}_{3}-\mathrm{MeOH}\right.$, 9:1).

IR (ATR): 2982, 2928, 2856, 2756, $1647 \mathrm{~cm}^{-1}$.

MS (EI): $m / z(\%)=222(20)\left[\mathrm{M}^{+}\right], 192(48), 149$ (100).

Anal. Calcd for $\mathrm{C}_{10} \mathrm{H}_{16} \mathrm{~N}_{5} \mathrm{O}: \mathrm{C}, 54.04 ; \mathrm{H}, 7.26 ; \mathrm{N}, 31.51$. Found: C, 53.90; $\mathrm{H}, 7.13 ; \mathrm{N}, 31.33$.

\section{[2,2,6,6-Tetramethyl-4-(1H-tetrazol-5-yl)piperidin-1-yl]oxidanyl}

(2c)

??; yield: $121 \mathrm{mg}$ (54\%); $\mathrm{mp} 169-170{ }^{\circ} \mathrm{C} ; R_{f}=0.23\left(\mathrm{CHCl}_{3}-\mathrm{MeOH}\right.$, 9:1).

IR (ATR): 2983, 2941, 2873, $1648 \mathrm{~cm}^{-1}$.

MS (EI): $m / z(\%)=224$ (10) [ $\left.\mathrm{M}^{+}\right], 194$ (3), 138 (100).

Anal. Calcd for $\mathrm{C}_{10} \mathrm{H}_{18} \mathrm{~N}_{5} \mathrm{O}$ : C, 53.55; $\mathrm{H}, 8.09 ; \mathrm{N}, 31.23$. Found: C, 53.36; $\mathrm{H}, 8.09$; N, 31.19.

\section{(3,4-Dicyano-2,2,5,5-tetramethyl-2,5-dihydro-1H-pyrrol-1-yl)oxi-} danyl (4)

In a well-ventilated hood, $\mathrm{Et}_{4} \mathrm{NCN}$ (374 mg, $2.4 \mathrm{mmol}$; CAUTION: Poisonous!) was added to a stirred solution of compound 3 (488 mg, 2.0 $\mathrm{mmol})$ in dry $\mathrm{MeCN}(15 \mathrm{~mL})$ at r.t.. The mixture was refluxed for $2 \mathrm{~h}$ then cooled and concentrated. The residue was partitioned between freshly prepared sat. aq $\mathrm{FeSO}_{4}(10 \mathrm{~mL})$ and EtOAc $(20 \mathrm{~mL})$. The organic phase was separated and the aqueous phase was extracted with EtOAc (20 mL). (Note: The aqueous phase was stored in a hazardousmaterials container.) The organic extracts were combined, dried $\left(\mathrm{MgSO}_{4}\right)$, filtered, and concentrated. The residue was subjected to flash column chromatography [silica gel, hexane- $\mathrm{Et}_{2} \mathrm{O}(2: 1)$ ] to give orange crystals; yield: $288 \mathrm{mg}(74 \%) ; \mathrm{mp} 141-142{ }^{\circ} \mathrm{C} ; R_{f}=0.41$ (hexane- $\mathrm{Et}_{2} \mathrm{O}, 2: 1$ ).

IR (ATR): 2982, 2915, 2852, 2234, $1648 \mathrm{~cm}^{-1}$.

MS (EI): $m / z(\%)=190(20)\left[\mathrm{M}^{+}\right], 160(27), 145$ (100).

Anal. Calcd for $\mathrm{C}_{10} \mathrm{H}_{12} \mathrm{~N}_{3} \mathrm{O}$ : C, 63.14; $\mathrm{H}, 6.36 ; \mathrm{N}, 22.09$. Found: $\mathrm{C}, 63.25$; H, 6.29; N, 21.98 .

\section{[3-Cyano-2,2,5,5-tetramethyl-4-(1H-tetrazol-5-yl)-2,5-dihydro- 1H-pyrrol-1-yl]oxidanyl (5)}

A mixture of $\mathrm{NaN}_{3}$ (390 mg, $6.0 \mathrm{mmol}$ ), $\mathrm{NH}_{4} \mathrm{Cl}$ (321 mg, $6.0 \mathrm{mmol}$ ), and dinitrile 4 (190 mg, $1.0 \mathrm{mmol})$ in DMF (10 mL) in a sealed tube was heated by microwave irradiation for $3 \mathrm{~h}$ (hold time) at $130^{\circ} \mathrm{C}$. The mixture was then cooled and concentrated in vacuo. The residue was partitioned between $5 \%$ aq $\mathrm{H}_{2} \mathrm{SO}_{4}(10 \mathrm{~mL})$ and $\mathrm{CHCl}_{3}(15 \mathrm{~mL})$. The organic phase was separated and the aqueous phase was washed with $\mathrm{CHCl}_{3}(20 \mathrm{~mL})$. The organic phases were combined, dried $\left(\mathrm{MgSO}_{4}\right)$, filtered, concentrated, and purified by flash column chromatography [silica gel, $\mathrm{CHCl}_{3}-\mathrm{Et}_{2} \mathrm{O}$ (4:1)] to give a yellow solid; yield: 91 (43\%); mp 206-207 ${ }^{\circ} \mathrm{C} ; R_{f}=0.19\left(\mathrm{CHCl}_{3}-\mathrm{MeOH}, 9: 1\right)$.

IR (ATR): 3167, 2922, 2852, 2236, $1658 \mathrm{~cm}^{-1}$.

MS (EI): $m / z(\%)=233(57)\left[\mathrm{M}^{+}\right], 218(8), 213$ (5) 42 (100).

Anal. Calcd for $\mathrm{C}_{10} \mathrm{H}_{13} \mathrm{~N}_{6} \mathrm{O}$ : C, 51.49; H, 5.62; N, 36.03. Found: C, 51.28; H, 5.65; N, 36.10.

\section{(3-Azido-4-cyano-2,2,5,5-tetramethyl-2,5-dihydro-1H-pyrrol-1-} yl)oxidanyl (6)

$\mathrm{NaN}_{3}$ (260 mg, $4.0 \mathrm{mmol}$ ) was added to a stirred bromo nitrile 3 (488 $\mathrm{mg}, 2.0 \mathrm{mmol})$ in DMF (5 mL) at r.t., and the mixture was stirred at $50{ }^{\circ} \mathrm{C}$ for $15 \mathrm{~min}$. The mixture was then diluted with $\mathrm{H}_{2} \mathrm{O}(40 \mathrm{~mL})$ and extracted with $\mathrm{Et}_{2} \mathrm{O}(2 \times 10 \mathrm{~mL})$. The organic phase was dried $\left(\mathrm{MgSO}_{4}\right)$, filtered, and concentrated. The residue was purified by flash column chromatography [silica gel, hexane- $\mathrm{Et}_{2} \mathrm{O}(4: 1)$ ] to give a yellow solid; yield: 144 (35\%); $\mathrm{mp} 45-46{ }^{\circ} \mathrm{C} ; R_{f}=0.54$ (hexane-Et ${ }_{2} \mathrm{O}, 2: 1$ ). IR (ATR): 2978, 2928, 2217, 2108, $1619 \mathrm{~cm}^{-1}$.

MS (EI): $m / z(\%)=206$ (19) [ $\left.\mathrm{M}^{+}\right], 147$ (13), 107 (23), 43 (100).

Anal. Calcd for $\mathrm{C}_{9} \mathrm{H}_{12} \mathrm{~N}_{5} \mathrm{O}: \mathrm{C}, 52.42 ; \mathrm{H}, 5.87 ; \mathrm{N}, 33.96$. Found: C, 52.31; H, 5.79; N, 34.01.

\section{(4,4,6,6-Tetramethyl-4,6-dihydropyrrolo[3,4-c]pyrazol-5(1H)- yl)oxidanyl (7)}

Method A: A mixture of $\mathrm{NaN}_{3}$ (130 mg, $2.0 \mathrm{mmol}$ ), $\mathrm{NH}_{4} \mathrm{Cl}$ (107 mg, 2.0 $\mathrm{mmol})$, and bromo nitrile $3(244 \mathrm{mg}, 1.0 \mathrm{mmol})$ in DMF $(10 \mathrm{~mL})$ in a sealed tube was heated by microwave irradiation for $2 \mathrm{~h}$ (hold time) at $130{ }^{\circ} \mathrm{C}$. The mixture was then cooled and concentrated under reduced pressure, and the residue was partitioned between brine (10 $\mathrm{mL})$ and $\mathrm{CHCl}_{3}(15 \mathrm{~mL})$. The organic phase was separated, and the aqueous phase was washed with $\mathrm{CHCl}_{3}(20 \mathrm{~mL})$. The organic phases were combined, dried $\left(\mathrm{MgSO}_{4}\right)$, filtered, concentrated, and purified by flash column chromatography [silica gel, hexane-EtOAc (2:1)] to give a yellow solid; $49 \mathrm{mg}(27 \%) ; \mathrm{mp} 217-218^{\circ} \mathrm{C} ; R_{f}=0.22$ (hexane-EtOAc, 2:1).

IR (ATR): 3353, 3231, 2974, 2927, 2853, 1670, $1617 \mathrm{~cm}^{-1}$.

MS (EI): $m / z(\%)=180(18)\left[\mathrm{M}^{+}\right], 165$ (67), 150 (100), 135 (45). 
Anal. Calcd for $\mathrm{C}_{9} \mathrm{H}_{14} \mathrm{~N}_{3} \mathrm{O}$ : C, 59.98; $\mathrm{H}, 7.83 ; \mathrm{N}, 23.32$. Found: C, 59.84; H, 7.78; N, 23.28.

Method B: A solution of cyano azide 6 (103 mg, $0.5 \mathrm{mmol})$ in DMF (5 $\mathrm{mL}$ ) was heated in a microwave oven for $2 \mathrm{~h}$ (hold time) at $130{ }^{\circ} \mathrm{C}$. After cooling, the solvent was concentrated off, the residue was partitioned between brine $(5 \mathrm{~mL})$ and $\mathrm{CHCl}_{3}(10 \mathrm{~mL})$. Workup as above gave a yellow solid [yield: $27 \mathrm{mg}(30 \%)$ ] that was identical to that obtained by Method A (mp, TLC, MS, and IR spectrum).

\section{[2,2,5,5-Tetramethyl-3-(5-methyl-1,3,4-oxadiazol-2-yl)-2,5-dihy- dro-1H-pyrrol-1-yl]oxidanyl (8)}

Method A: Compound 2a (416 mg, $2.0 \mathrm{mmol}$ ) was dissolved in $\mathrm{Ac}_{2} \mathrm{O}(5$ $\mathrm{mL}$ ), and the mixture was heated in a microwave oven at $90^{\circ} \mathrm{C}$ for $1 \mathrm{~h}$ (hold time). The mixture was cooled then poured onto ice-water (50 $\mathrm{mL}$ ) to give a precipitate. The precipitate was collected by filtration, air-dried, and purified by flash column chromatography [silica gel, hexane-EtOAc (2:1)] to give a yellow solid; yield: $280 \mathrm{mg}(63 \%) ; \mathrm{mp}$ $104-105^{\circ} \mathrm{C} ; R_{f}=0.2$ (hexane-EtOAc, $2: 1$ ).

IR (ATR): 2975, 2928, 2854, 1668, 1648, $1577 \mathrm{~cm}^{-1}$.

${ }^{1} \mathrm{H}$ NMR [?? MHz, $\mathrm{CDCl}_{3}+(\mathrm{PhNH})_{2}$ ]: $\delta=6.42(\mathrm{~s}, 1 \mathrm{H}), 2.57(\mathrm{~s}, 3 \mathrm{H}), 1.61$ (s, $6 \mathrm{H}), 1.28(\mathrm{~s}, 6 \mathrm{H})$.

MS (EI): $m / z(\%)=222(53)\left[\mathrm{M}^{+}\right], 207$ (45), 192 (26), 177 (100).

Anal. Calcd for $\mathrm{C}_{11} \mathrm{H}_{16} \mathrm{~N}_{3} \mathrm{O}_{2}$ : C, 59.44; $\mathrm{H}, 7.26 ; \mathrm{N}, 18.91$. Found: C, 59.33; H, 7.28; N, 18.73 .

Method B: Compound $\mathbf{2 a}$ (416 mg, $2.0 \mathrm{mmol}$ ) was dissolved in $\mathrm{Ac}_{2} \mathrm{O}$ ( 5 $\mathrm{mL}$ ), and the solution was heated $90^{\circ} \mathrm{C}$ for $1 \mathrm{~h}$ in an oil bath. The mixture was cooled, poured onto ice-water $(50 \mathrm{~mL})$, basified by adding solid $\mathrm{K}_{2} \mathrm{CO}_{3}(\mathrm{pH} 9)$, and extracted with $\mathrm{CHCl}_{3}(2 \times 20 \mathrm{~mL})$. The extracts were dried $\left(\mathrm{MgSO}_{4}\right)$, filtered, concentrated, and purified by flash column chromatography [silica gel, hexane-EtOAc (2:1)] to give a yellow solid [yield: $200 \mathrm{mg}(45 \%)$ ] that was identical to the compound obtained by Method A (mp, TLC, MS, and IR spectrum).

\section{3,3'-(1,3,4-Oxadiazole-2,5-diyl)bis(2,2,5,5-tetramethyl-2,5-dihy- dro-1H-pyrrol-1-yloxidanyl) (10)}

A solution of acid chloride $\mathbf{9}$ ( $405 \mathrm{mg}, 2.0 \mathrm{mmol}$ ) in anhyd toluene (5 $\mathrm{mL}$ ) was added to a mixture of tetrazole $2 \mathrm{a}(416 \mathrm{mg}, 2.0 \mathrm{mmol})$ and pyridine (158 mg, $2.0 \mathrm{mmol})$ in anhyd toluene $(10 \mathrm{~mL})$. The mixture was heated to $90{ }^{\circ} \mathrm{C}$ for $1 \mathrm{~h}$ then cooled. The solvent was evaporated and the residue was dissolved in $\mathrm{CHCl}_{3}(20 \mathrm{~mL})$. The solution was washed successively with $5 \% \mathrm{aq} \mathrm{H}_{2} \mathrm{SO}_{4}(10 \mathrm{~mL})$ and brine $(20 \mathrm{~mL})$. The organic phase was dried $\left(\mathrm{MgSO}_{4}\right)$, filtered, and concentrated. The residue was purified by column chromatography [silica gel, hexane-EtOAc (2:1)] to give a yellow solid; yield: $186 \mathrm{mg}$ (54\%); $\mathrm{mp} 185-186{ }^{\circ} \mathrm{C}$; $R_{f}=0.26$ (hexane-EtOAc, $2: 1$ ).

${ }^{1} \mathrm{H}$ NMR [?? $\mathrm{MHz}, \mathrm{CDCl}_{3}+(\mathrm{PhNH})_{2}$ ]: $\delta=6.56(\mathrm{~s}, 2 \mathrm{H}), 1.66(\mathrm{~s}, 12 \mathrm{H})$, $1.43(\mathrm{~s}, 12 \mathrm{H})$.

IR (ATR): 2977, 2930, 1706, $1644 \mathrm{~cm}^{-1}$.

MS (EI): $m / z(\%)=346(23)\left[\mathrm{M}^{+}\right], 286$ (43), 271 (54), 67 (100).

Anal. Calcd for $\mathrm{C}_{18} \mathrm{H}_{26} \mathrm{~N}_{4} \mathrm{O}_{3}$ : C, 62.41; $\mathrm{H}, 7.56 ; \mathrm{N}, 16.17$. Found: $\mathrm{C}$, 62.33; H, 7.30; N, 16.22 .

\section{Paramagnetic $\alpha$-Azido Acrylates 12a, 12b, and 15a; General Proce- dure}

A solution of NaOEt, freshly prepared by dissolving $\mathrm{Na}$ (230 mg, 10.0 $\mathrm{mmol})$ in $\mathrm{EtOH}(10 \mathrm{~mL})$, was added dropwise over $10 \mathrm{~min}$ to a stirred solution of the appropriate aldehyde $(5.0 \mathrm{mmol})$ and $\mathrm{EtO}_{2} \mathrm{CCH}_{2} \mathrm{~N}_{3}$
(1.29 g $10.0 \mathrm{mmol})$ in anhyd $\mathrm{EtOH}(15 \mathrm{~mL})$ at $-10^{\circ} \mathrm{C}$, and the mixture was stirred at $0{ }^{\circ} \mathrm{C}$ for $2 \mathrm{~h}$. The reaction was then quenched with sat. aq $\mathrm{NH}_{4} \mathrm{Cl}(30 \mathrm{~mL}) . \mathrm{CH}_{2} \mathrm{Cl}_{2}(30 \mathrm{~mL})$ was added, the phases were separated, and the aqueous phase was washed with $\mathrm{CH}_{2} \mathrm{Cl}_{2}(2 \times 20 \mathrm{~mL})$. The organic phases were combined, washed with brine $(15 \mathrm{~mL})$, dried $\left(\mathrm{MgSO}_{4}\right)$, filtered, concentrated, and purified by column chromatography. Compounds 12a and 12b were stable for several days if stored in a freezer $\left(-20^{\circ} \mathrm{C}\right)$. During workup, we observed spontaneous formation of the cyclized products $\mathbf{1 3 a}$ and $\mathbf{1 3 b}$.

[3-(2-Azido-3-ethoxy-3-oxoprop-1-en-1-yl)-2,2,5,5-tetramethyl2,5-dihydro-1H-pyrrol-1-yl]oxidanyl (12a)

Yellow solid; yield: 488 (35\%); $\mathrm{mp}$ ?? ${ }^{\circ} \mathrm{C}(\mathrm{dec}) ; R_{f}=0.55$ (hexaneEtOAc, 2:1).

IR (ATR): 2975, 2931, 2108, 1714, $1613 \mathrm{~cm}^{-1}$. MS (EI): $m / z(\%)=279(6)\left[\mathrm{M}^{+}\right], 221(20), 163(31), 42$ (100).

Anal. Calcd for $\mathrm{C}_{13} \mathrm{H}_{19} \mathrm{~N}_{4} \mathrm{O}_{3}$ : C, 55.90; H, 6.86; N, 20.06. Found: C, 55.74; H, 6.77; N, 19.99 .

[4-(2-Azido-3-ethoxy-3-oxoprop-1-en-1-yl)-2,2,6,6-tetramethyl3,6-dihydropyridin-1(2H)-yl]oxidanyl (12b)

Orange solid; yield: $278 \mathrm{mg}$ (19\%); $\mathrm{mp}$ ?? ${ }^{\circ} \mathrm{C}(\mathrm{dec}) ; R_{f}=0.61$ (hexaneEtOAc, 2:1).

IR (ATR): 2977, 2933, 2106, 1710, $1606 \mathrm{~cm}^{-1}$.

${ }^{1} \mathrm{H}$ NMR (?? $\left.\mathrm{MHz}, \mathrm{CDCl}_{3}\right): \delta(0$-acetate $)=6.44(\mathrm{~s}, 1 \mathrm{H}), 5.90(\mathrm{~s}, 1 \mathrm{H})$, 4.34-4.30 (q, J= 7.1 Hz, $2 \mathrm{H}), 2.14(\mathrm{~s}, 1 \mathrm{H}), 1.38(\mathrm{t}, J=7.1 \mathrm{~Hz}, 3 \mathrm{H}), 1.37$ (s, $3 \mathrm{H}), 1.22$ (d, J= 3.3 Hz, $6 \mathrm{H}), 1.18(\mathrm{~s}, 3 \mathrm{H})$.

MS (EI): $m / z(\%)=293(35)\left[\mathrm{M}^{+}\right], 220$ (52), 162 (93), 42 (100).

Anal. Calcd for $\mathrm{C}_{14} \mathrm{H}_{21} \mathrm{~N}_{4} \mathrm{O}_{3}$ : C, 57.32; H, 7.22; N, 19.10. Found: C, 57.12; H, 7.07; N, 19.02 .

\{3-[4-(2-Azido-3-ethoxy-3-oxoprop-1-en-1-yl)phenyl]-2,2,5,5-tetramethyl-2,5-dihydro-1H-pyrrol-1-yl\}oxidanyl (15a)

Brownish-yellow solid; yield: $1.06 \mathrm{~g}(60 \%) ; \mathrm{mp} 75-76{ }^{\circ} \mathrm{C} ; R_{f}=0.51$ (hexane-EtOAc, 2:1).

IR (ATR): 2972, 2114, 1700, $1603 \mathrm{~cm}^{-1}$.

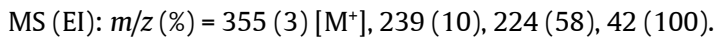

Anal. Calcd for $\mathrm{C}_{19} \mathrm{H}_{23} \mathrm{~N}_{4} \mathrm{O}_{3}$ : C, 64.21; $\mathrm{H}, 6.52 ; \mathrm{N}, 15.76$. Found: $\mathrm{C}$, 64.07; H, 6.35; N, 15.61 .

Ethyl 3-\{4-[1-(acetyloxy)-2,2,5,5-tetramethyl-2,5-dihydro-1H-pyrrol-3-yl]phenyl\}-2-azidoacrylate (15b)

Ascorbic acid ( $1.75 \mathrm{~g}, 10.0 \mathrm{mmol}$ ) was added in portions over $15 \mathrm{~min}$ to a stirred solution of compound $\mathbf{1 5 a}$ ( $710 \mathrm{mg}, 2.0 \mathrm{mmol}$ ) in 1,4-dioxane $(20 \mathrm{~mL})$ and $\mathrm{H}_{2} \mathrm{O}(10 \mathrm{~mL})$ at $40{ }^{\circ} \mathrm{C}$ under $\mathrm{N}_{2}$. The solution was then extracted with $\mathrm{CHCl}_{3}(2 \times 20 \mathrm{~mL})$, and the extracts were dried $\left(\mathrm{MgSO}_{4}\right) \cdot \mathrm{Et}_{3} \mathrm{~N}(220 \mathrm{mg}, 2.2 \mathrm{mmol})$ and $\mathrm{AcCl}(172 \mathrm{mg}, 2.2 \mathrm{mmol})$ were added successively under $\mathrm{N}_{2}$ at $0{ }^{\circ} \mathrm{C}$, and the solution was stirred at r.t. for $1 \mathrm{~h}$. EtOH ( $1 \mathrm{~mL})$ was then added, the mixture was filtered, and the filtrate was concentrated. The residue was treated with brine $(10 \mathrm{~mL})$ and EtOAc $(20 \mathrm{~mL})$, and the phases were separated. The aqueous phase was extracted with EtOAc $(2 \times 10 \mathrm{~mL})$. The organic phases were combined, dried $\left(\mathrm{MgSO}_{4}\right)$, filtered, concentrated, and purified by chromatography [silica gel, hexane-EtOAc (2:1)] to give a colorless oil; yield: 581 (73\%); $R_{f}=0.50$ (hexane-EtOAc, $2: 1$ ).

IR (ATR): 2975, 2934, 2112, 1757, 1699, 1603, $1564 \mathrm{~cm}^{-1}$. 
${ }^{1} \mathrm{H}$ NMR (?? $\left.\mathrm{MHz}, \mathrm{CDCl}_{3}\right): \delta=7.80(\mathrm{~d}, J=8.3 \mathrm{~Hz}, 2 \mathrm{H}), 7.39(\mathrm{~d}, J=8.4$ $\mathrm{Hz}, 2 \mathrm{H}), 6.91$ (s, $1 \mathrm{H}), 5.80$ (s, $1 \mathrm{H}), 4.42-4.38$ (q, J = 7.1 Hz, $2 \mathrm{H}), 2.21$ $(\mathrm{s}, 3 \mathrm{H}), 1.44-1.41(\mathrm{t}, J=7.1 \mathrm{~Hz}, 3 \mathrm{H}), 1.35(\mathrm{~s}, 9 \mathrm{H}), 1.29(\mathrm{~s}, 3 \mathrm{H})$.

MS (EI): $m / z(\%)=398(2)\left[\mathrm{M}^{+}\right], 370(12), 355$ (8), 43 (100).

Anal. Calcd for $\mathrm{C}_{21} \mathrm{H}_{26} \mathrm{~N}_{4} \mathrm{O}_{4}: \mathrm{C}, 63.30 ; \mathrm{H}, 6.58 ; \mathrm{N}, 14.06$. Found: $\mathrm{C}$, $63.14 ; \mathrm{H}, 6.50 ; \mathrm{N}, 13.99$.

\section{Cyclization of $\alpha$-azido acrylates 2a, 12b, and 15b; General Proce- dure}

A solution of compound $\mathbf{1 2 a}, \mathbf{1 2 b}$, or $\mathbf{1 5 b}(1.0 \mathrm{mmol})$ in anhyd hexane $(5 \mathrm{~mL})$ was heated in a sealed tube equipped with a Weflon disk at 70 $\mathrm{W}$ constant power for $10 \mathrm{~min}$ (total irradiation time). The solution was then cooled to r.t., and the crude product was collected by filtration and washed with hexane.

\section{[2-(Ethoxycarbonyl)-4,4,6,6-tetramethyl-4,6-dihydropyrrolo[3,4-} b]pyrrol-5(1H)-yl]oxidanyl (13a)

Yellow crystals; yield: $205 \mathrm{mg}(82 \%) ; \mathrm{mp} 173-174{ }^{\circ} \mathrm{C} ; R_{f}=0.61$ (hexane-EtOAc, 2:1).

IR (ATR): 3267, 2975, 2922, 1673, 1482, $1431 \mathrm{~cm}^{-1}$.

${ }^{1} \mathrm{H}$ NMR [?? $\left.\mathrm{MHz}, \mathrm{CDCl}_{3}+(\mathrm{PhNH})_{2}\right]: \delta=6.78(\mathrm{~s}, 1 \mathrm{H}), 4.41-4.37(\mathrm{q}, J=$ $6.8 \mathrm{~Hz}, 2 \mathrm{H}), 1.48(\mathrm{~s}, 6 \mathrm{H}), 1.44-1.41(\mathrm{t}, J=6.9 \mathrm{~Hz}, 3 \mathrm{H}), 1.16(\mathrm{~s}, 6 \mathrm{H})$.

MS (EI): $m / z(\%)=251(3)\left[\mathrm{M}^{+}\right], 221$ (100), 206 (86), 160 (62).

Anal. Calcd for $\mathrm{C}_{13} \mathrm{H}_{19} \mathrm{~N}_{2} \mathrm{O}_{3}: \mathrm{C}, 62.13 ; \mathrm{H}, 7.62 ; \mathrm{N}, 11.15$. Found: $\mathrm{C}$, $62.22 ; \mathrm{H}, 7.58 ; \mathrm{N}, 11.05$.

\section{[2-(Ethoxycarbonyl)-5,5,7,7-tetramethyl-1,4,5,7-tetrahydro-6H-} pyrrolo[2,3-c]pyridin-6-yl]oxidanyl (13b)

Orange crystals; yield: $185 \mathrm{mg}(70 \%) ; \mathrm{mp} 186-187^{\circ} \mathrm{C} ; R_{f}=0.71$ (hexane-EtOAc, 2:1).

IR (ATR): 3326, 2989, 12977, 1677, $1510 \mathrm{~cm}^{-1}$.

MS (EI): $m / z(\%)=265$ (24) [ $\left.\mathrm{M}^{+}\right], 235$ (35), 220 (54), 192 (100).

Anal. Calcd for $\mathrm{C}_{14} \mathrm{H}_{21} \mathrm{~N}_{2} \mathrm{O}_{3}$ : C, 63.37; H, 7.98; N, 10.56. Found: C, $63.50 ; \mathrm{H}, 7.99 ; \mathrm{N}, 10.43$.

Ethyl 6-[1-(acetyloxy)-2,2,5,5-tetramethyl-2,5-dihydro-1H-pyrrol3-yl]-1H-indole-2-carboxylate (16b)

White crystals; yield: $240 \mathrm{mg}(65 \%) ; \mathrm{mp} 114-116{ }^{\circ} \mathrm{C} ; R_{f}=0.60$ (hexane-EtOAc, 2:1).

${ }^{1} \mathrm{H} \mathrm{NMR}\left(? ? \mathrm{MHz}, \mathrm{CDCl}_{3}\right): \delta=7.65(\mathrm{~d}, J=8.3 \mathrm{~Hz}, 1 \mathrm{H}), 7.40(\mathrm{~s}, 1 \mathrm{H}), 7.23$ $(\mathrm{s}, 1 \mathrm{H}), 7.17(\mathrm{~d}, J=8.2 \mathrm{~Hz}, 1 \mathrm{H}), 5.76(\mathrm{~s}, 1 \mathrm{H}), 4.46-4.41(\mathrm{q}, J=7.1 \mathrm{~Hz}, 2$ H), $2.22(\mathrm{~s}, 3 \mathrm{H}), 1.58(\mathrm{~s}, 6 \mathrm{H}), 1.46-1.43(\mathrm{t}, J=7.2 \mathrm{~Hz}, 3 \mathrm{H}), 1.37(\mathrm{~s}, 6 \mathrm{H})$.

${ }^{13} \mathrm{C}$ NMR (?? MHz, ??): $\delta=171.6,161.7,145.1,136.6,132.9,131.4$, $128.1,126.9,122.3,121.2,110.5,108.5,72.2,68.2,61.1,27.9,23.5$, 19.3, 14.4 .

MS (EI): $m / z(\%)=370(15)\left[\mathrm{M}^{+}\right], 355$ (92), 313 (98), 43 (100).

Anal. Calcd for $\mathrm{C}_{21} \mathrm{H}_{26} \mathrm{~N}_{2} \mathrm{O}_{4}$ : C, 68.09; $\mathrm{H}, 7.07 ; \mathrm{N}, 7.56$. Found: C, 67.94; $\mathrm{H}, 7.05 ; \mathrm{N}, 7.69$.

\{3-[2-(Ethoxycarbonyl)-1H-indol-6-yl]-2,2,5,5-tetramethyl-2,5-dihydro-1H-pyrrol-1-yl\}oxidanyl (16a)

Freshly prepared NaOEt [Na metal (69 mg, $3.0 \mathrm{mmol}$ ) dissolved in anhyd EtOH ( $5 \mathrm{~mL})$ ] was added to a solution of acetate $\mathbf{1 6 b}$ (370 mg, 1.0 $\mathrm{mmol})$ in dry EtOH $(10 \mathrm{~mL})$. The mixture was stirred at r.t. for $1 \mathrm{~h}$ then concentrated. The residue was partitioned between ?? aq $\mathrm{NH}_{4} \mathrm{Cl}$ (10 $\mathrm{mL})$ and $\mathrm{CH}_{2} \mathrm{Cl}_{2}(20 \mathrm{~mL})$, and the organic phase was separated and dried $\left(\mathrm{MgSO}_{4}\right)$. $\mathrm{MnO}_{2}(87 \mathrm{mg}, 1.0 \mathrm{mmol})$ was added and $\mathrm{O}_{2}$ was bub- bled through the mixture for $30 \mathrm{~min}$. The mixture was then filtered and concentrated. The residue was purified by column chromatography [silica gel, hexane-EtOAc (2:1)] to give a yellow solid; yield: 232 $\mathrm{mg}(71 \%) ; \mathrm{mp} 136-137^{\circ} \mathrm{C} ; R_{f}=0.55$ (hexane-EtOAc, $2: 1$ ).

IR (ATR): 3320, 2974, 2922, 2852, 1677, $1521 \mathrm{~cm}^{-1}$.

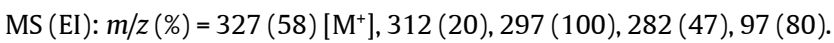
Anal. Calcd for $\mathrm{C}_{19} \mathrm{H}_{23} \mathrm{~N}_{2} \mathrm{O}_{3}$ : C, 69.70; $\mathrm{H}, 7.08 ; \mathrm{N}, 8.56$. Found: C, 69.51; $\mathrm{H}, 7.06 ; \mathrm{N}, 8.33$.

\section{(2,2,6,6-Tetramethyl-4-nitro-3,6-dihydropyridin-1(2H)-yl)oxi- danyl (18)}

DBU (480 mg, $3.1 \mathrm{mmol}$ ) was added to a solution of compound $\mathbf{1 7}$ ( $840 \mathrm{mg}, 3.0 \mathrm{mmol}$ ) in anhyd $\mathrm{MeCN}(10 \mathrm{~mL})$, and the mixture was refluxed for $15 \mathrm{~min}$. The mixture was then cooled to r.t. and concentrated. The residue was partitioned between EtOAc $(20 \mathrm{~mL})$ and $5 \% \mathrm{aq} \mathrm{H}_{2}-$ $\mathrm{SO}_{4}(10 \mathrm{~mL})$. The organic phase was separated, dried $\left(\mathrm{MgSO}_{4}\right)$, filtered, and concentrated. The residue was purified by flash chromatography [silica gel, hexane-EtOAc (2:1)] to give deep-orange crystals; yield: $288 \mathrm{mg}$ (48\%); $\mathrm{mp} 50-51^{\circ} \mathrm{C} ; R_{f}=0.41$ (hexane- $\mathrm{Et}_{2} \mathrm{O}, 2: 1$ ).

IR (ATR): 2974, 2924, 2853, 1680, $1516 \mathrm{~cm}^{-1}$.

${ }^{1} \mathrm{H}$ NMR [?? $\mathrm{MHz}, \mathrm{CDCl}_{3}+(\mathrm{PhNH})_{2}$ ]: $\delta=7.05(\mathrm{~s}, 1 \mathrm{H}), 2.67(\mathrm{~s}, 2 \mathrm{H}), 1.39$ (s, $6 \mathrm{H}), 1.26(\mathrm{~s}, 6 \mathrm{H})$.

MS (EI): $m / z(\%)=199$ (31) $\left[\mathrm{M}^{+}\right], 185$ (31), 169 (27) 152 (42), 139 (100).

Anal. Calcd for $\mathrm{C}_{9} \mathrm{H}_{15} \mathrm{~N}_{2} \mathrm{O}_{3}$ : C, 54.26; $\mathrm{H}, 7.59 ; \mathrm{N}, 14.06$. Found: C, 54.12; $\mathrm{H}, 7.55 ; \mathrm{N}, 14.01$.

(4,4,6,6-Tetramethyl-1,4,6,7-tetrahydro-5H-[1,2,3]triazolo[4,5c]pyridin-5-yl)oxidanyl (19)

$\mathrm{NaN}_{3}$ (130 mg, $2.0 \mathrm{mmol}$ ) was added to a solution of compound $\mathbf{1 8}$ (199 $\mathrm{mg}, 1.0 \mathrm{mmol})$ in DMSO $(5.0 \mathrm{~mL})$, and the mixture was stirred at $90{ }^{\circ} \mathrm{C}$ for $2 \mathrm{~h}$. The mixture was then cooled, diluted with $\mathrm{H}_{2} \mathrm{O}(10 \mathrm{~mL})$, and extracted with $\mathrm{CH}_{2} \mathrm{Cl}_{2}(3 \times 30 \mathrm{~mL})$. The organic phases were combined, dried $\left(\mathrm{MgSO}_{4}\right)$, filtered, and concentrated. The crude product was purified by column chromatography [silica gel, hexane-EtOAc (2:1)] to give a yellow solid; yield: $92 \mathrm{mg}(47 \%) ; \mathrm{mp} 198-199^{\circ} \mathrm{C} ; R_{f}=$ 0.22 (hexane-EtOAc, 2:1).

IR (ATR): 3148, 3053, 2969, 2876, 1582, $1530 \mathrm{~cm}^{-1}$.

${ }^{1} \mathrm{H}$ NMR [?? MHz, $\mathrm{CDCl}_{3}+(\mathrm{PhNH})_{2}$ ]: $\delta=2.88(\mathrm{~s}, 2 \mathrm{H}), 1.65(\mathrm{~s}, 6 \mathrm{H}), 1.33$ (s, $6 \mathrm{H})$.

MS (EI): $m / z(\%)=195$ (23) [ $\left.\mathrm{M}^{+}\right], 165$ (45), 150 (73) 122 (37), 41 (100). Anal. Calcd for $\mathrm{C}_{9} \mathrm{H}_{15} \mathrm{~N}_{4} \mathrm{O}$ : C, 55.37; H, 7.74; N, 28.70. Found: C, 55.25; H, 7.64; N, 28.59 .

[3-(Methoxycarbonyl)-4,4,6,6-tetramethyl-2,4,6,7-tetrahydro-5Hpyrrolo[3,4-c]pyridin-5-yl]oxidanyl (20a)

DBU (729 mg, $4.8 \mathrm{mmol}$ ) was added dropwise to a stirred solution of compound 18 (796 mg, $4.0 \mathrm{mmol}$ ) and methyl isocyanoacetate (435 $\mathrm{mg}, 4.4 \mathrm{mmol})$ in anhyd THF $(10 \mathrm{~mL})$ at $0{ }^{\circ} \mathrm{C}$, and the mixture was stirred at r.t. for $12 \mathrm{~h}$. The solvent was evaporated and the residue was partitioned between EtOAc ( $30 \mathrm{~mL}$ ) and $5 \%$ aq $\mathrm{H}_{2} \mathrm{SO}_{4}(20 \mathrm{~mL})$. The phases were separated and the organic phase was dried $\left(\mathrm{MgSO}_{4}\right)$, filtered, and concentrated. The residue was purified by column chromatography [silica gel, hexane-EtOAc (2:1)] to give a pale-orange solid; yield: $532 \mathrm{mg}$ (53\%); $\mathrm{mp} 184-185^{\circ} \mathrm{C} ; R_{f}=0.45$ (hexane-EtOAc, $2: 1$ ). IR (ATR): 3330, 2987, 2943, 1701, 1572, $1513 \mathrm{~cm}^{-1}$.

${ }^{1} \mathrm{H}$ NMR [?? $\mathrm{MHz}, \mathrm{CDCl}_{3}+(\mathrm{PhNH})_{2}$ ]: $\delta=6.57(\mathrm{~s}, 1 \mathrm{H}), 3.89(\mathrm{~s}, 3 \mathrm{H}), 2.67$ (s, $2 \mathrm{H}), 1.79$ (s, $6 \mathrm{H}), 1.32(\mathrm{~s}, 6 \mathrm{H})$. 
MS (EI): $m / z(\%)=251(38)\left[\mathrm{M}^{+}\right], 221$ (18), 206 (55), 178 (74) 146 (100).

Anal. Calcd for $\mathrm{C}_{13} \mathrm{H}_{19} \mathrm{~N}_{2} \mathrm{O}_{3}$ : C, 62.13; H, 7.62; N, 11.15. Found: C, 62.10; $\mathrm{H}, 7.47 ; \mathrm{N}, 11.05$.

[3-(tert-Butoxycarbonyl)-2-(methoxycarbonyl)-4,4,6,6-tetramethyl-2,4,6,7-tetrahydro-5H-pyrrolo[3,4-c]pyridin-5-yl]oxidanyl (20b) $t$-BuOK (90 mg, $0.8 \mathrm{mmol}$ ) was added to a stirred solution of compound 20a (502 mg, $2.0 \mathrm{mmol})$ and $\mathrm{Boc}_{2} \mathrm{O}(480 \mathrm{mg}, 2.2 \mathrm{mmol})$ in anhyd THF $(20 \mathrm{~mL})$ at r.t., and the mixture was stirred and refluxed for $19 \mathrm{~h}$. If the conversion was not complete, more $\mathrm{Boc}_{2} \mathrm{O}(91 \mathrm{mg}, 0.5$ $\mathrm{mmol})$ and $t$-BuOK $(22 \mathrm{mg}, 0.2 \mathrm{mmol})$ were added, and reflux and stirring were continued for a further $5 \mathrm{~h}$. The mixture was then cooled and concentrated, and the residue was partitioned between brine $(10 \mathrm{~mL})$ and EtOAc $(20 \mathrm{~mL})$. The organic phase was dried $\left(\mathrm{MgSO}_{4}\right)$, filtered, concentrated, and purified by flash column chromatography [silica gel, hexane- $\mathrm{Et}_{2} \mathrm{O}(2: 1)$ ] to give an orange solid; yield: $512 \mathrm{mg}$ (73\%); $\mathrm{mp} 90-91^{\circ} \mathrm{C} ; R_{f}=0.27$ (hexane-Et ${ }_{2} \mathrm{O}, 2: 1$ ).

IR (ATR): 2980, 2922, 2853, 1725, $1516 \mathrm{~cm}^{-1}$.

MS (EI): $m / z(\%)=351(38)\left[\mathrm{M}^{+}\right], 278$ (8), 264 (13), 221 (41) 206 (60), $178(100) 57$ (70).

Anal. Calcd for $\mathrm{C}_{18} \mathrm{H}_{27} \mathrm{~N}_{2} \mathrm{O}_{5}$ : C, 61.34; $\mathrm{H}, 8.01 ; \mathrm{N}, 7.95$. Found: C, 61.19; H, 7.98; N, 8.03.

11-(tert-Butoxycarbonyl)-9,10-bis(ethoxycarbonyl)-1-(methoxycarbonyl)-3,3,5,5-tetramethyl-4,11-diazatricyclo[6.2.1.0 2,7$]$ undeca-2(7),9-dien-4-yloxidanyl (21)

A solution of compound $20 \mathbf{b}$ (702 mg, $2.0 \mathrm{mmol}$ ) and $\mathrm{EtO}_{2} \mathrm{CC} \equiv \mathrm{CCO}_{2} \mathrm{Et}$ $(680 \mathrm{mg}, 4.0 \mathrm{mmol})$ in toluene $(20 \mathrm{~mL})$ was refluxed for $48 \mathrm{~h}$ then cooled. The solvent was evaporated and the residue was purified by flash column chromatography [silica gel, hexane-EtOAc (2:1)] to give a deep-yellow oil; yield: $354 \mathrm{mg}(34 \%) ; R_{f}=0.40$ (hexane-EtOAc, $2: 1$ ). IR (ATR): 2980, 2938, 2905, 1712, $1628 \mathrm{~cm}^{-1}$.

MS (EI): $m / z(\%)=521(2)\left[\mathrm{M}^{+}\right], 491$ (2), 391 (36), 251 (46), 178 (82), 146 (98), 57 (100).

Anal. Calcd for $\mathrm{C}_{26} \mathrm{H}_{37} \mathrm{~N}_{2} \mathrm{O}_{9}$ : C, 59.87; $\mathrm{H}, 7.15 ; \mathrm{N}, 5.37$. Found: $\mathrm{C}, 60.02$; H, 7.23; N, 5.25 .

\section{Acknowledgment}

We are grateful to Dr. Gábor Maász for mass spectral measurements, to Viola Csokona for elemental analyses, and to the Hungarian National Research Fund (OTKA K81123, K104956) for financial support.

\section{Supporting Information}

Supporting information for this article is available online at http://dx.doi.org/10.1055/s-0034-1379958.

\section{References}

(1) Li, J. J. Heterocyclic Chemistry in Drug Discovery; Wiley: Hoboken, 2013.

(2) Likhtenshtein, G.; Yamauchi, J.; Nakatsuji, S.; Smirnov, A. I.; Tamura, R. Nitroxides: Applications in Chemistry Biomedicine and Materials Science; Wiley-VCH: Weinheim, 2008.
(3) Tebben, L.; Studer, A. Angew. Chem. Int. Ed. 2011, 50, 5034.

(4) Shelke, S. A.; Sigurdsson, S. T. In Structural Information from Spin-Labels and Intrinsic Paramagnetic Centres in the Biosciences; Timmel, C.; Harmer, J. R., Eds.; Springer: Berlin, 2011, Chap. 3, 121.

(5) Ratera, I.; Veciana, J. Chem. Soc. Rev. 2012, 41, 303.

(6) Fawzi, N. L.; Fleissner, M. R.; Anthis, N. J.; Kálai, T.; Hideg, K.; Hubbell, W. L.; Clore, G. M. J. Biomol. NMR 2011, 51, 105.

(7) Kálai, T.; Jekő, J.; Hideg, K. Synthesis 2000, 831.

(8) Kálai, T.; Jekő, J.; Berente, Z.; Hideg, K. Synthesis 2006, 439.

(9) Kálai, T.; Balog, M.; Jekő, J.; Hideg, K. Synthesis 1998, 1476.

(10) Kulcsár, Gy.; Kálai, T.; Jekő, J.; Hideg, K. Synthesis 2003, 1361.

(11) Kálai, T.; Bagi, N.; Jekő, J.; Berente, Z.; Hideg, K. Synthesis 2010. 1702.

(12) Kálai, T.; Altman, R.; Maezawa, I.; Balog, M.; Morisseau, C.; Petrlova, J.; Hammock, D. B.; Jin, L-W.; Trudell, J. R.; Voss, C. J.; Hideg, K. Eur. J. Med. Chem. 2014, 77, 343.

(13) Rozant sev, E. G. Free Nitroxyl Radicals; Plenum: New York, 1970.

(14) Wong, L. T.; Schwenk, R.; Hsia, J. C. Can. J. Chem. 1974, 52, 3381.

(15) Rauckman, E. J.; Rosen, G. M.; Abou-Donia, M. B. J. Org. Chem. 1976, $41,564$.

(16) Finnegan, W. G.; Henry, R. A.; Lofquist, R. J. Am. Chem. Soc. 1958, $80,3908$.

(17) Qiao, J. X. In Name Reactions in Heterocyclic Chemistry II; Li, J. J., Ed.; Wiley: Hoboken, 2011, Chap. 5.5, 309.

(18) Efimova, J. A.; Artamanova, T. V.; Koldobskii, G. I. Russ. J. Org. Chem. 2008, 44, 1345.

(19) Kokorin, A. I.; Golubeva, E. N.; Mladenova, B. Y.; Tran, V. A.; Kálai, T.; Hideg, K.; Grammp, G. Appl. Magn. Reson. 2013, 44, 1041.

(20) Hemetsberger, K.; Knittel, D. Monatsh. Chem. 1972, 103, 194.

(21) Lehmann, F.; Holm, M.; Laufer, S. Tetrahedron Lett. 2009, 50, 1708.

(22) Hideg, K.; Hankovszky, H. O.; Lex, L.; Kulcsár, Gy. Synthesis 1980, 911.

(23) Csekő, J.; Hankovszky, H. O.; Hideg, K. Can. J. Chem. 1985, 63, 940.

(24) Murakami, Y.; Watanabe, T.; Suzuki, H.; Kotake, N.; Takahashi, T.; Toyonari, K.; Ohno, M.; Takase, K.; Suzuki, T.; Kondo, K. Chem. Pharm. Bull. 1997, 45, 1739.

(25) Kálai, T.; Balog, M.; Szabó, A.; Gulyás, G.; Jekő, J.; Sümegi, B.; Hideg, K. J. Med. Chem. 2009, 52, 1619.

(26) Hideg, K.; Sár, P. C.; Hankovszky, H. O.; Tamás, T.; Jerkovich, Gy. Synthesis 1993, 390.

(27) Kálai, T.; Rozsnyai, B.; Jerkovich, Gy.; Hideg, K. Synthesis 1994, 1079.

(28) (a) Barton, D. H. R.; Zard, S. Z. J. Chem. Soc., Chem. Commun. 1985, 1098. (b) Gribble, G. W. In Name Reactions in Heterocyclic Chemistry; Li, J. J.; Corey, E. J., Eds.; Wiley: Hoboken, 2005, Chap. 2.1, 69 .

(29) Miskina, L. A.; Podvigina, L. F. Izv. Akad. Nauk, Ser. Khim. 1982, 1338; Chem. Abstr. 1982, 97, 109838.

(30) Keene, C.; Kürti, L. Synthesis 2013, 45, 1719.

(31) Ono, N.; Kawamura, H.; Bougauchi, M.; Murayama, K. Tetrahedron 1990, 46, 7483.

(32) Kaiser, H. P.; Muchowski, J. M. J. Org. Chem. 1984, 49, 4203.

(33) Kálai, T.; Bognár, B.; Zsolnai, D.; Berente, Z.; Hideg, K. Synthesis 2012, 44, 3655. 